\title{
BORDERLINE PERSONALITY DISORDER WITH PARANOID ELEMENTS
}

\author{
Alexandra-Cristina Anghel ${ }^{1}$, Daria-Elvira Cosma ${ }^{1}$, Ramona Năstase ${ }^{1}$,
}

\author{
Simona Trifu 2 (iD) \\ ${ }^{1}$ Faculty of Psychology and Educational Sciences, University of Bucharest, Bucharest, Romania \\ 2 "Carol Davila" University of Medicine and Pharmacy, Bucharest, Romania
}

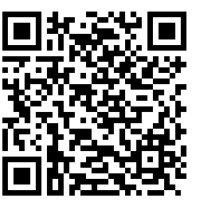

DOI: https://doi.org/10.29121/granthaalayah.v9.i3.2021.3796

Article Type: Research Article

Article Citation: Alexandra-Cristina

Anghel, Daria-Elvira Cosma,

Ramona Năstase, Simona

Trifu. (2021). BORDERLINE

PERSONALITY DISORDER WITH

PARANOID ELEMENTS.

International Journal of Research -

GRANTHAALAYAH, 9(3), 190-194.

https://doi.org/10.29121/granthaa

layah.v9.i3.2021.3796

Received Date: 15 March 2021

Accepted Date: 31 March 2021

Keywords:

Borderline Personality

Deficient Individualization

Paranoid Core

Antisocial,

Addiction

Bipolar Disorder

\section{ABSTRACT}

The case of patient $\mathrm{V}$ is one you want to dig for, being an example in which a Cluster B disorder (i.e., borderline personality disorder) is also accompanied by elements from Cluster A (such as those in the paranoid area). Symptoms from the dependent personality can be involved.

Objective: The presentation of a medical case of an 18-year-old young man, initially diagnosed at the age of 16 with Bipolar Affective Personality Disorder, and whose personality structure is better explained by a Borderline Disorder is the aim of the present article.

Method: The patient was hospitalized involuntarily. He was under medical supervision and treatment. He also underwent specialized investigations (EEG, brain CT), psychological and personality tests, as well as daily monitoring. Throughout the procedure there have been a collaboration with his family and the authorities.

Results: From the detailed anamnesis and the reconstruction of the significant life events, a borderline personality structure emerged, having a paranoid core that provided $V$ the capacity of being goal-oriented. The personality scales also showed elements of an antisocial nature, manipulation and desire to be socially liked. Psychodynamic interpretations show an emotional flattening, avoidance of being in touch with he's own emotions and feelings, his unconscious mind housing an unbearable pain.

Conclusions: The diagnosis of Bipolar Personality Disorder, sustained two years ago, is refuted, the patient being included in an axis II frame (i.e. borderline personality with a strong paranoid core and pathology of addiction)

\section{INTRODUCTION}

The present study refers to a male patient, V, 18 years old that is student and not married, living with parents. The patient was in 12th grade at the time of the interview $\mathrm{V}$ is an only child and was raised by his maternal grandfather until he was 7 years old. At the age of 7, his parents decided to bring him to school in Bucharest. The patient was living at the time of the interview with his mother and father. The mother took over the responsibility

(C) 2021 The Author(s). This is an open access article distributed under the terms of the Creative Commons Attribution License, which permits unrestricted use, distribution, and reproduction in any medium, provided the original author and source are credited. 
of educating $\mathrm{V}$, and the father was quite disinterested in the boy's development. Instead, he was rather preoccupied with gambling, bars and alcohol. The family was in the middle class in terms of income and social status. The family climate was described as harmonious up to the age of 7 years. Afterwards, it was characterized by a lack of harmony.

$\mathrm{V}$ specified that his high school admission grade was 8.13. Thus, he managed to enter the $6^{\text {th }}$ on the list at his first high school option.

Incidents, accidents at school: he had a crisis at school, which resulted in blows and destruction of objects.

Group integration, relationships with peers, with superiors: the interaction with teachers was a conflictual one. He stated that he often wanted to draw their attention towards some issues he considered unproperly approached, asking various questions. Thus, V's interaction with teachers was quite tense. In terms of relationships with peers, $\mathrm{V}$ was often accused by teachers of negatively influencing his classmates, meaning that some of the students tended to copy V's rebellious attitude towards the educational system and the manner of conducting the classes. Also, it is important to specify that in V's educational history there were two transfers: once, in the $5^{\text {th }}$ grade, and the second time in the $11^{\text {th }}$ grade. These class transfers were made because of V's defiant behavior, but also because of the extremely high absenteeism rate.

\section{HISTORY OF PSYCHOLOGICAL DISEASE}

Debut: $V$ had several crises as a child. The first affective crisis took place at the age of 7 , at school, when his parents decided to bring him to school in Bucharest. The outbreaks resulted in blows and destruction of surrounding objects. The outbreaks took place due to the fact that from the age of $7, \mathrm{~V}$ witnessed a lot of heated quarrels between his parents, but also because of the longing for his grandfather. V was separated from his grandfather against his wish to stay with him. After those crises, the teachers asked one of the parents to stay with V during school breaks to make sure he did not have other crises. Thus, it was decided that the father should resign and look after $\mathrm{V}$, the mother having a higher salary. V stated that, during middle school, he was" deeply hurt" romantically by several girls. Here, V's shortcomings in terms of imposition and respecting boundaries. He said about himself that, at the time, he was behaving" like a desperate" when it came to girls.

Later, in high school, $\mathrm{V}$ felt unable to get out of hurtful relationships, and when confronted with a partner's loss he had a hard time accepting the breakup. From a romantic relationship of this sort, another crisis resulted, namely, the one in which $\mathrm{V}$ climbed on the block's roof and threatened to throw himself (as means to manipulating his girlfriend, emotional blackmail). Another fact that is worth mentioning, in terms of the patient's history of the disorder, is related to another of V's romantic relationship. He wanted to seduce a girl in order to have sex with her. After succeeding, they continued to meet and have frequent sexual contact. Later, he began to put a lot of psychological pressure on the girl to get her to defy her father and earn her freedom. $V$ also started treating him disrespectfully. Due to this fact, her father requested a restraining order against the patient, but $\mathrm{V}$ did not respect it saying instead:" So what? I want to go to jail, I love her, I don't care, take me to jail", thus defying the law, the same way he did with the educational system. Because of this, he stayed one night at the police station.

$\mathrm{V}$ also had a history of self-mutilation due to his inability to accept that his girlfriend could no longer see him. He cut himself with a razor blade in the past for a similar reason. In addition, another way of self-harm was when he took 84 paracetamol pills, all of this because he did not know how to cope with suffering and inner emptiness. Another important aspect to specify would be that during hospitalization, he was not compliant to the treatment, having a low level of disease awareness.

\section{INTERPRETATIONS IN THE PSYCHO-BEHAVIORAL REGISTER}

The onset of the disorders in the psycho-behavioral register was at the age of 7, when V's parents decided to take him to a school in Bucharest, which also meant the separation from his maternal grandfather, with whom $V$ had lived until that time. Afterwards, the first critical situation occurred, when V became very agitated at school, and after a psychiatric hospitalization, he was diagnosed with ADHD and Opposition Disorder. Since then, his life has been permanently" sprinkled" with cristical situations (e.g., the episode in which he climbed on the block being drunk and with the intention of throw himself, the fight with his girlfriend's father).

$\mathrm{V}$ is constantly looking for attention. Judging by the fact that he likes to talk about himself, his need to gain the admiration and validation of others becomes noticeable. Even towards the end of the interview, when he considered 
that the psychiatrist was no longer listening to him, he expressed his dissatisfaction. All this emphasis that he displays in his interactions, has the role of protecting him, as the trauma of rejection from the past has caused him emotional distress.

Out of the need of living any moment at maximum intensity, he is constantly looking for extreme situations. All this" fights" he's having with his girlfriend's father in court are a" pleasure" for the patient. Thus, there is a symbolic transition" from the persecuted to the persecutor." In his childhood, he felt like a victim of others (of his parents' quarrels, of the girls who made fun of him), and this determined him to fight for what he wants in teenage years, without feeling any remorse at any moment. He uses manipulation as a" weapon" to achieve his goals (e.g., he convinces his peers to rebel against the teachers, he convinces his girlfriend to have sex on the staircase of the block and to defy her too restrictive father).

During the interview, it was possible to observe, from the answers offered, an accentuated fear of abandonment, especially regarding romantic relationships ("don't let me down"). His relations with the girls he talks about are tumultuous and characterized by a highly developed sexuality. The patient has a symbiotic level of functioning, as he has difficulties regarding separation-individualization. His psychism is always in touch with" another", in this case the romantic partner. In fact, $\mathrm{V}$ himself states that his emotional and behavioral problems are explained by an" extremely unconscious and profound identification with an external source of psychological gratification, in this case a relationship with a person."

In terms of behavior, there are self-mutilating acts and suicide attempts. Against the background of intense emotions with a negative tone, $\mathrm{V}$ cut himself with a razor blade several times in his past. He talks more about the last such episode, which happened as a result to his girlfriend's father's ban on keeping in touch with his daughter. Similarly, after breaking up with his first girlfriend, V climbed on the block's roof and consumed alcohol, intending to commit suicide.

Among its main coping mechanisms when dealing with negative feelings was alcohol consumption. He also developed an addiction to gambling, like his father, stating that he could not resist the urge to play, because it helped him to position himself in the present moment. He feels an unconscious anger towards his father, whom he blames for his vices. $V$ claims that before he started playing himself, he felt hatred towards people who did this, and after he went on talking about how his father urged him to play for the first time. He also felt ashamed and outraged when his father showed up at the hospital being drunk.

\section{ELEMENTS OF PSYCHIATRIC DIAGNOSIS}

Borderline personality disorder involves: separation/individualization issues; affective control problems; intense personal attachments that occupy a central position, in addition to self-image problems. At the time of the interview, $\mathrm{V}$ seemed to present behaviors from the paranoid area, since he is in a constant struggle with the education system as well as with law. It also manifests certain behaviors in the antisocial sphere: manipulation of others; lack of remorse; refusing treatment. Regarding borderline personality disorder, the following can be identified: being in a" permanent crisis"; threatening, self-destructive and suicide attempts; tumultuous relationships, frenetic efforts to avoid abandonment; predisposition to anger; manipulative attitude, unstable selfimage and identity, impulsiveness regarding money and sexuality; excessive alcohol consumption; dispositional reactivity ("storm of affects") (APA, 2013). Adjacent elements of a general symptomatic area would be: separating from he's own emotionality as a defense mechanism; language is scientific," from the book," without emotional charge; apparent state of calmness.

\section{THE STRESS-DIATHESIS MODEL}

\subsection{PSYCHIC EXAMINATION OF THE PRESENT STATE}

During the examination, the patient presented himself in a neat, even studied outfit, with an air of impeccability and pedantry. He was cooperative, maintaining eye contact throughout the interview, keeping a fixed, arrogant gaze. He kept a self-confident body position in his chair, holding a bottle of water in his hand, which he used as an" anchor" when he needed to refocus on his own ego, and when certain questions managed to reach his vulnerable spots. 


\section{Alexandra-Cristina Anghel, Daria-Elvira Cosma, Ramona Năstase, Simona Trifu}

The patient has a broad, rich and argumentative discourse, presenting a tendency towards philosophizing, but lacking substance. His gestures and facial expressivity were very supple, supporting an accelerated rhythm and ideoverbal flow. He manifests concerns for justice, fairness, elements used to justify his behavior. Emotional detachment gives way to egocentrism that emphasizes arrogance in all his manifestations.

In his speech, $\mathrm{V}$ has sudden transitions from the idealization of his loved one, to his devaluation, typical attitude for the borderline area. He admits he is emotionally confused and that he can find himself only in a symbiosis with another being:" ... Extremely unconscious and deep identification with an external source of psychological gratification, in this case a relationship with a person. (...) My inner self has been looking for a sense of identity. All the ideals we've been looking for in life, we've been looking for them in relation to another being."

\subsection{PSYCHODYNAMIC INTERPRETATION}

" The lack of love during childhood made me not have a self-identity. My inner self has searched until now for sense of identity." Through all the behaviors he does, V seems to say "Look at me! I'm here too! And not anywhere! Here, UP HIGH!" Left in the care of his grandfather until the age of 7, he was deprived of his parents' love, which trigger feelings of inadequacy and devaluation. Over time those feelings were being translated into a sense of injustice and anger, crystallized in acts of rebellion and struggle, behaviors used as defense mechanisms. He builds a castle for himself and put a crown on the head embellished with a false sense of self-importance and high selfesteem, threatened by any disagreement.

Attachment disorders shed light on his personality structure by highlighting the addictive elements." I need YOU to exist"," I need to fight to be SOMEONE" and not anyone" I fought two colonels" (important people, thus I am too). Dependent attachment comes with a strong need to be validated by others, especially by partners and friends. Those who have an insecure attachment run the risk of becoming true harassers if the gifts they offer out of" love" don't arouse reciprocity. They also find it extremely difficult to metabolize a refusal or the fact that someone no longer wants them around.

At the age of seven, he had the first behavioral pathology triggered by his separation from his grandfather. The sadness that any child could feel in such a situation has reached catastrophic proportions, unleashing the anger accumulated throughout this period. The event was only the spark that ignited the fire that had been burning inside for a long time. The wick was just waiting to be lit.

At the age of 16, his grandfather's death activated the dimension of anger and injustice again.

He started feeling that something was "wrong" inside, so he tried to find comfort in philosophy and psychology. He manages to explain his behaviors, but these explanations

cannot reach the core of his being. Therefore, they remain only on the surface, on rationalization level, and he uses them to embellish his ego. He seems to understand the mechanisms at the rational level, but the value and depth of meaning remains unknown. The explanations become his" precious" when there is nothing else left.

The conflicts that $\mathrm{V}$ has with his parents are not in classic areal of the child-parent fight. He is not fighting with ordinary people; he is fighting with colonies and systems like the educational one and the one of justice. These fights have a very significant magnitude. He needs these conflicts in order to feel important, to become important, to get attention, to switch the role of the victim with the role of the persecutor, to become feared, to be seen, to have value. And so, the parents finally have the opportunity to see him, there on the top of the world. Probably out of guilt, the parents passively witness this whole deployment of forces.

The drive of his paranoid core gives him the strength to aim for his goal. He is a perpetually dissatisfied individual and a fighter against an oppressive system (i.e., the social system, family etc., all needing to be improved). He has attempts to manipulate the entourage, the loved one (" yes, I was manipulating her, I can say that"), he uses rationalization to justify his own behaviors and put them back on the line of correctness ("It is not stupid the one who asks, but the one who gives") - manifestations typical of narcissism. He is very argumentative and demands that those around him encourage his efforts in order to maintain his self-confidence. He has a behavior typical of a person in a position of authority. He acts like" a king without a crown." He has charisma and the drive and manifestations of a leader that must be followed and approved. If not, there will be splits and crisis (Gabbard, 2007). Being egocentric, he can be easily offended. This is a feature of the narcissistic-paranoid structure. It would not be out of the question for this side to become dominant and transcend the borderline coloration. 
To sum up, when it comes to romantic attachments, $\mathrm{V}$ reveals his borderline structure, and when confronting the authorities, he emphasizes his paranoid core. Regarding sexual exhibitionism and self-mutilation, he not only aims to draw attention, but he also expresses the pleasure of living dangerously (Cavazzi \& Beccera, 2014). We have, therefore, manifestations from Cluster B, with elements of borderline, narcissism and antisocial, intricate with dependent notes. If at first, he wanted confirmation, now he seeks attention, in time his emotional mood migrating to emotional indifference.

Also, noteworthy is the presence of the perverse nucleus that can be seen in the desirable manner in which he behaves in the hospital, as well as when he has the opportunity to present himself to others, managing to become very desirable, and also in the way he does the plan for the Court." I've been strong and cunning", suggests proud antisocial behavior. But we don thave to forget that behind all of these manifestations of force is the unloved child, who feel that he is not worthy of love, he is not enough, the child who wants to demonstrate himself, the child who want to understand why and later becomes the adult in search of meaning, but whose paranoid core is extremely strong and it keeps him on the surface of a deficient intellectualization. He struggled from an early age so much, that become a habit.

Also, $\mathrm{V}$ has a depression that has not been fully experienced and that now brings him in the plane of emotional flattening. He just doesn't want to feel anymore because it's too painful. He seems to have found his answers in books and the authors he refers to on countless occasions. In the attempt to anchor in reality, he uses the book" The Power of the Present". The present for him, however, is a temporary place of refuge, because as long as he doesn't face his true "enemies" - the demons of the past will always harass him.

\section{DEFENSE MECHANISMS}

V uses denial as defense mechanisms, as well as poor intellectualization. Paradoxically, although he accurately describes the elements of mental and behavioral dysfunction, he denies the idea of a psychiatric diagnosis.

\section{CONCLUSION}

The diagnosis of Bipolar Personality Disorder, sustained two years ago, is refuted, the patient being included in an axis II frame (i.e., borderline personality with a strong paranoid core and pathology of addiction).

\section{SOURCES OF FUNDING}

This research received no specific grant from any funding agency in the public, commercial, or not-for-profit sectors.

\section{CONFLICT OF INTEREST}

The author have declared that no competing interests exist.

\section{ACKNOWLEDGMENT}

None.

\section{REFERENCES}

[1] American Psychiatric Association. (2013). Diagnostic and statistical manual of mental disorders (5th ed.). Arlington, VA: Author.

[2] Cavazzi, T. \& Beccera, R. (2014). Psychophysiological Research of Borderline Personality Disorder: Review and Implications for Biosocial Theory. Europe's Journal of Psychology. 10(1): 185-203.

[3] Gabbard, G. (2017). Psychodynamic Psychiatry in Clinical Practice. Washington, DC: Amer Psychiatric Pub. 